\title{
PRODUKSI PROTEIN REKOMBINAN HORMON PERTUMBUHAN IKAN KERAPU
}

\author{
Irvan Faizal"), Ratu Siti Aliah"), Muhammad Husni Amarullah"), \\ Novi Megawati*, Sutanti*), dan Alimuddin ${ }^{* *}$ \\ *) Pusat Teknologi Produksi Pertanian \\ Badan Pengkajian dan Penerapan Teknologi (BPPT) \\ Jl. M.H. Thamrin No. 8, Jakarta 10340 \\ E-mail: irvan.faizal@bppt.go.id; irvan_faizal@yahoo.com \\ ${ }^{* *}$ Departemen Budidaya Perairan, FPIK-Institut Pertanian Bogor \\ Jl. Agatis, Kampus IPB Darmaga, Bogor 16680
}

(Naskah diterima: 28 Desember 2011; Disetujui publikasi: 1 Juni 2012)

\begin{abstract}
ABSTRAK
Salah satu spesies ikan yang menjadi target produksi perikanan budidaya nasional adalah ikan kerapu tikus (Cromileptes altivelis). Ikan kerapu tikus merupakan ikan laut budidaya komoditas ekspor, namun laju pertumbuhannya sangat lambat. Oleh karena itu, perlu dilakukan usaha budidaya yang mampu menaikkan laju pertumbuhan ikan kerapu tikus. Pendekatan nutrisi melalui penggunaan hormon pertumbuhan (Growth Hormone, GH) pada usaha budidaya diyakini mampu meningkatkan kecepatan tumbuh ikan budidaya. Pada penelitian ini, melalui teknologi DNA rekombinan telah dilakukan isolasi dan identifikasi gen $\mathrm{GH}$ yang selanjutnya dilakukan produksi protein rekombinan GH (recombinant Growth Hormone, rGH) dengan memanfaatkan penggunaan bakteri E. coli. Dalam pelaksanaan penelitian dilakukan konstruksi $\mathrm{rGH}$ yang menghasilkan bakteri E. coli BL2 1 (DE3) yang mampu memproduksi protein rGH. Produksi rGH dilakukan pada skala bioreaktor. Proses isolasi produk $\mathrm{rGH}$-nya dalam bentuk pellet inclusion bodies yang selanjutnya dicampur dengan pelet pakan komersil hingga konsentrasi akhir protein dalam pakan mencapai $1 \mathrm{ng} / 6 \mathrm{mg}$ pakan, di mana setelah dikering-anginkan, pelet pakan protein rekombinan $\mathrm{GH}$ dapat diaplikasikan untuk budidaya ikan kerapu tikus dan ikan budidaya lainnya.
\end{abstract}

KATA KUNCl: protein rekombinan, hormon pertumbuhan, kerapu tikus, pakan

ABSTRACT: Production of grouper growth hormone recombinant protein. By: Irvan Faizal, Ratu Siti Aliah, Muhammad Husni Amarullah, Novi Megawati, Sutanti, and Alimuddin

Humpback grouper is one of the most cultured fishes in Asia, including Indonesia, since its highly economical price and one of the superior commodities in fish aquaculture. The main problem facing in humpback culture is its low growth rate. Its long production time makes the operational cost of this fish aquaculture increases drastically. Therefore, developing a right method that will be more effective and efficient to solve the problem is pressingly needed. The main factor that influences the growth is growth hormone. To surpass those problems, we try to use protein recombination technique that produces recombinant growth hormone abundantly in 
bacteria. In this research, recombinant Growth Hormone $(\mathrm{rGH})$ has been constructed then transformed to E. coli BL21 (DE3) producing recombinant protein growth hormone in a bioreactor. The $\mathrm{rGH}$ product is an inclusion bodies formed then that added to a commersial feed at the final concentration $\mathrm{rGH}$ product is $1 \mathrm{ng} \mathrm{rGH} / 6 \mathrm{mg}$ feed. Subsequently, after air dried processing, the rGH have been applied in grouper aquaculture to accelerate grouper growth rate.

\section{KEYWORDS: recombinant protein, growth hormone, humpback grouper, feed}

\section{PENDAHULUAN}

Produksi perikanan budidaya pada tahun 2014 ditargetkan naik sebesar $353 \%$ dari produksi perikanan nasional tahun 2009. Karena perikanan tangkap tidak bisa diharapkan lagi untuk bisa meningkatkan kapasitas produksinya, maka target tersebut bertumpu pada perikanan budidaya. Di antara spesies ikan budidaya yang menjadi target produksi perikanan nasional adalah ikan kerapu tikus (Cromileptes altivelis).

Ikan kerapu tikus merupakan ikan laut budidaya komoditas ekspor dengan harga jual yang relatif mahal, sekitar US\$ 40 per $\mathrm{kg}$, namun laju pertumbuhannya sangat lambat; membutuhkan waktu sekitar 1,5 tahun untuk mencapai ukuran konsumsi 500-600 g/ekor. Oleh karena itu, perlu dilakukan usaha budidaya yang mampu menaikkan laju pertumbuhan ikan kerapu tikus. Pendekatan nutrisi melalui penggunaan hormon pertumbuhan (Growth Hormone, GH) pada usaha budidaya diyakini mampu meningkatkan kecepatan tumbuh ikan budidaya (Hayami et al., 1989; Kapuscinski \& Hallerman, 1990). Melalui teknologi DNA rekombinan dapat diisolasi dan diidentifikasi gen $\mathrm{GH}$ yang selanjutnya dapat dilakukan produksi protein rekombinan GH (recombinant Growth Hormone, $\mathrm{rGH}$ ) dengan memanfaatkan penggunaan bakteri E. coli (Watahiki et al., 1992; Jeh et al., 1997).

Untuk mendukung usaha budidaya yang mampu menaikkan laju pertumbuhan ikan budidaya, maka pada penelitian ini dilakukan konstruksi rGH yang menghasilkan bakteri $E$. coli BL21 (DE3) yang mampu memproduksi protein $\mathrm{rGH}$. Proses isolasi produk $\mathrm{rGH}$-nya dalam bentuk pelet inclusion bodies yang selanjutnya dicampur dengan pelet pakan komersil agar dapat diaplikasikan untuk budidaya ikan kerapu tikus dan ikan budidaya lainnya.

\section{BAHAN DAN METODE}

\section{Kloning GH}

Plasmid pGEM-T Easy yang mengandung gen ktGH (kerapu tikus Growth Hormone) digunakan sebagai cetakan untuk mengamplifikasi sekuen mature protein GH. Primer yang digunakan dalam amplifikasi ktGH adalah 5'-TTCATCCAGCTGATGATTGCCAGATGTAAC3' dan 5'-AGTTGGCTTCAGGAGAGAGTCG ACATTTAG-3'. Produk amplifikasi PCR difragmentasi menggunakan elektroforesis DNA dengan gel agarosa, pita DNA dengan panjang sekitar 700 bp dipotong dari gel agarosa dan dipurifikasi menggunakan kit (GeneAid). Hasil purifikasi DNA diligasi kembali ke pGEM-T Easy (Promega, USA) untuk perbanyakan DNA, yang akan digunakan dalam pembuatan vektor ekspresi rekombinan protein (Sambrook \& Russel, 2001).

\section{Konstruksi rGH}

Untuk membentuk konstruksi rGH dilakukan konstruksi pGEM-TEasy-ktGH yang membawa gen ktGH di dalam host non ekspresi $E$. coli $\mathrm{DH} 5 \alpha$ dengan menggunakan transformasi elektroporasi (Probosari, 2009). Kemudian dilakukan digestion menggunakan enzim EcoRI. Gen ktGH diligasikan dengan vektor ekspresi pETBlue-2 (Novagen) (Anonymous, 2004) untuk menciptakan konstruksi baru, pBlueKNKT. Konstruksi pBlueKNKT ditransformasikan ke dalam E. coli Novablue untuk membentuk E. coli yang siap memproduksi rGH.

\section{Produksi rGH}

Sebanyak 1 koloni positif bakteri E. coli BL2 1 (DE3) dikultur di dalam $200 \mathrm{~mL}$ medium LB cair yang mengandung antibiotik selama $14-15$ jam pada suhu $37^{\circ} \mathrm{C}$. Kemudian, sebanyak $50 \mathrm{~mL}$ hasil kultur ditumbuhkan lagi di dalam $450 \mathrm{~mL}$ medium cair yang baru selama 
3 jam. Pada suhu $37^{\circ} \mathrm{C}$ dan di-shaker dengan kecepatan $150 \mathrm{rpm}$. Setelah 3 jam, ditambahkan $5 \mathrm{~mL}$ IPTG $100 \mathrm{mM}$ dan inkubasi selama 2 jam pada suhu $37^{\circ} \mathrm{C}$ dengan kecepatan $150 \mathrm{rpm}$. Tiap $350 \mathrm{~mL}$ kultur dipindah ke tabung sentrifuse dan didinginkan di $4^{\circ} \mathrm{C}$ selama 1 jam. Selanjutnya disentrifuse dingin selama 20 menit pada kecepatan 8.000 rpm. Bagian supernatan dibuang, dan pelet digabungkan. Pelet diresuspensikan dengan $50 \mathrm{~mL}$ PBS dingin + 0,1\% (v/v) Triton X-100. Campuran disonikasi dengan kekuatan penuh sambil direndam es. Kemudian dicuci sebanyak dua kali dengan $25 \mathrm{~mL} 1 \mathrm{M} \mathrm{NaCl}+1 \%$ (v/v) Triton X-100 dan disentrifuse dingin selama 20 menit pada kecepatan $8.000 \mathrm{rpm}$. Selanjutnya supernatan dibuang dan pelet dicuci dengan $50 \mathrm{~mL}$ PBS. Dilakukan sentrifugasi dingin selama 20 menit pada kecepatan $8.000 \mathrm{rpm}$ dan pelet disimpan difreezer $-20^{\circ} \mathrm{C}$.

\section{Pembuatan pakan protein $\mathrm{rGH}$}

Sebanyak $5 \mathrm{mg}$ pelet $\mathrm{rGH}$ hasil produksi di dalam bioreaktor dilarutkan di dalam 0,3\% $(\mathrm{w} / \mathrm{v})$ amonium asetat yang mengandung 250 mg HP-55. Kemudian, dikering-bekukan selama 12 jam menghasilkan GH-EMP (Growth Hormone Enteric Polymer Matrix) dan diresuspensi dalam 0,01 asam asetat yang mengandung $10 \mathrm{mM} \mathrm{NaCl}$ dan $0,013 \%(\mathrm{w} / \mathrm{v})$ deoxycholic acid sampai protein mencapai konsentrasi $0,5 \mathrm{mg} / \mathrm{mL}$ (pelarut alkohol absolut). Selanjutnya dicampur dengan pelet komersil (kurang lebih $3 \mathrm{~kg}$ pakan) di dalam bak besar hingga konsentrasi akhir protein dalam pakan mencapai $1 \mathrm{ng} \mathrm{rGH/6} \mathrm{mg} \mathrm{pakan}$ dan dikering-anginkan pada kondisi sekitar yang panas selama maksimal 5 jam.

\section{HASIL DAN BAHASAN}

\section{Konstruksi rGH}

Dalam konstruksi rGH, gen ktGH diligasikan dengan vektor ekspresi pETBlue-2 untuk menghasilkan konstruksi baru pBlueKNKT. Konstruksi pBlueKNKT ditransformasikan ke dalam E. coli Novablue untuk membentuk $E$. coli yang siap memproduksi rGH. Gambar 1 menunjukkan koloni $E$. coli Novablue hasil transformasi pBlueKNKT pada cawan yang tumbuh pada medium SOB agar yang mengandung IPTG, X-gal, dan ampicillin. Terdapat koloni berwarna putih yang menandakan adanya insert berupa konstruksi pBlueKNKT. Koloni-koloni putih yang tumbuh ini selanjutnya berhasil ditumbuhkan di dalam medium cair $2 \times Y T$. Selanjutnya, kultur ini diisolasi plasmidnya, di-digest dengan enzim EcoRI, dan elektroforesis.

Gambar 2 menunjukkan bahwa dari enam sampel yang dielektroforesis, hanya muncul tiga pita DNA, yaitu pada sampel nomor 1, 3, dan 4. Pita DNA yang muncul pada sampel

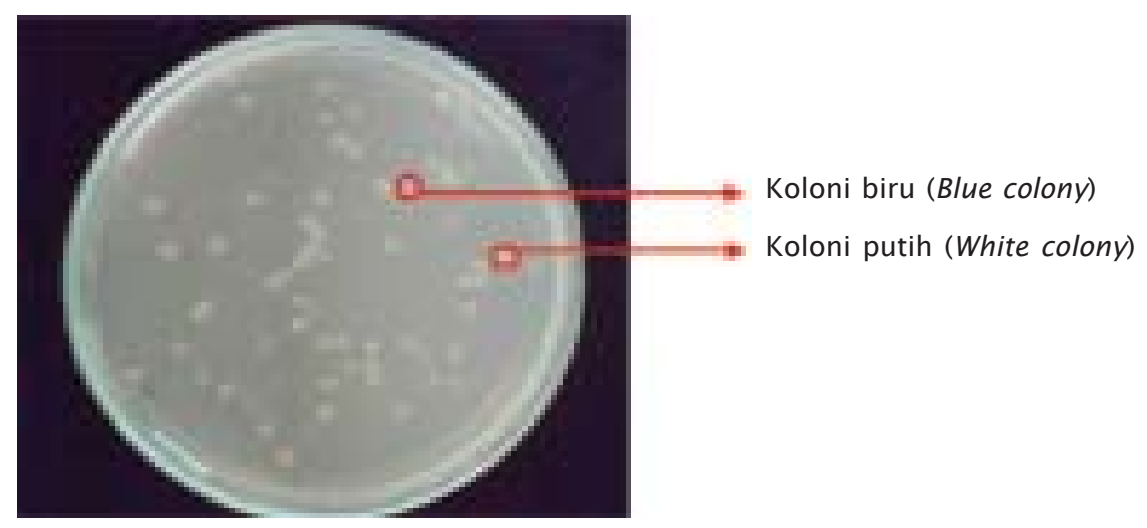

Gambar 1. Koloni E. coli Novablue hasil transformasi pBlueKNKT yang mengandung ktGH. Koloni biru: tanpa insert ktGH; koloni putih: mengandung insert ktGH

Figure 1. E.coli Novablue colonies containing plasmid pBlueKNKT transformant producing ktGH. Blue colony: no ktGH insert; white colony: containing $k t G H$ insert 


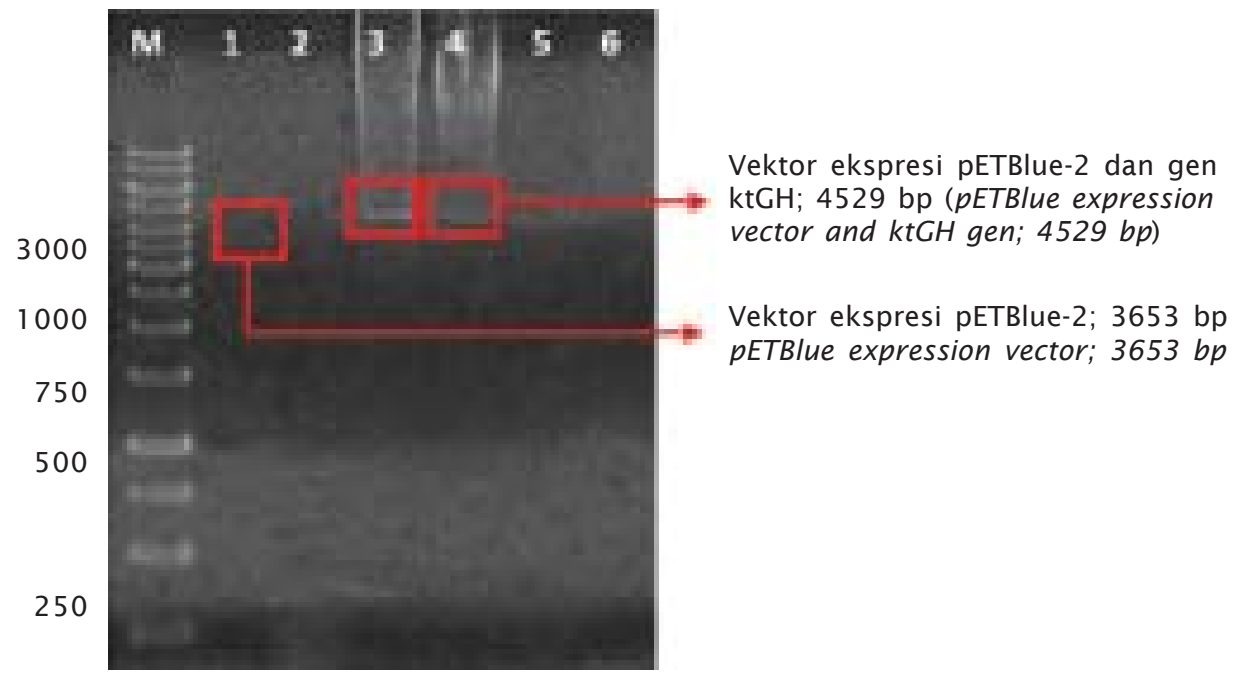

Gambar 2. Hasil elektroforesis single digestion konstruksi pBlueKNKT untuk verifikasi insert ktGH. 1-6: sampel hasil digest pBlueKNKT; M: 1 kb marker

Figure 2 Electrophoresis result of single digestion pBlueKNKT construction to verify ktGH insert. 1-6: pBlueKNKT digestion result; $M$ : $1 \mathrm{~kb}$ marker

nomor 1 menunjukkan bahwa sampel tersebut tidak mengandung insert gen $\mathrm{ktGH}$, yang ditunjukkan dengan panjang fragmen pita DNA sebesar \pm 3653 bp. Sedangkan pita DNA yang muncul pada sampel nomor 3 dan 4 menunjukkan adanya insert gen ktGH, yang ditunjukkan dengan panjang fragmen pita DNA sebesar $\pm 4529 \mathrm{bp}$. Keberhasilan kloning gen $\mathrm{ktGH}$ pada vektor ekspresi pETBlue-2 ini diduga karena vektor ekspresi pETBlue-2 ini bukan hasil perbanyakan dari generasi ke generasi sehingga kemungkinan terjadinya kerusakan pada vektor ini adalah kecil, sehingga vektor ekspresi pETBlue-2 ini dapat tersambung dengan insert secara sempurna. Selain itu, juga karena sifat plasmid ini yang merupakan plasmid high copy number, karena merupakan turunan dari pUC (Syaifuddin et al., 2007), sehingga konstruksi dapat ter-maintain dengan lebih baik di dalam vektor ekspresi pETBlue-2. Selain itu, karena vektor ekspresi pETBlue-2 ini memiliki gen lacz yang lebih memudahkan deteksi koloni positif. Dengan demikian dapat disimpulkan bahwa kloning gen ktGH pada vektor ekspresi pETBlue-2 menghasilkan konstruksi pBlueKNKT berhasil dilakukan, sehingga dapat dilakukan tahapan selanjutnya yaitu produksi rGH menggunakan E. coli BL2 1 (DE3) hasil kloning dengan nomor koloni 3 dan 4.

\section{Produksi rGH dan pakan protein rGH}

Produksi rGH menggunakan E. coli BL2 1 (DE3) hasil kloning pada tahapan konstruksi rGH. Tahapan awal adalah melakukan inokulasi 1 koloni positif bakteri BL2 1 (DE3) pada 200 $\mathrm{mL}$ medium cair yang mengandung antibiotik selama $14-15 \mathrm{jam}$ pada suhu $37^{\circ} \mathrm{C}$. Kemudian sebanyak $50 \mathrm{~mL}$ hasil kultur ditumbuhkan lagi di dalam $450 \mathrm{~mL}$ medium cair yang baru selama 3 jam yang kemudian diinduksi produksi rGH dengan penambahan IPTG. Kemudian dilakukan proses isolasi rGH dalam bentuk pelet inclusion bodies sesuai yang dijelaskan di metodologi (Acosta et al., 2007).

Dalam pembuatan pakan protein $\mathrm{rGH}$ dilakukan pelarutan pelet inclusion bodies $\mathrm{rGH}$ ke dalam $0,3 \%(\mathrm{w} / \mathrm{v})$ amonium asetat yang mengandung HP-55 yang selanjutnya dikeringbekukan selama semalam (Tsai et al., 1995; Tsai et al., 1997). Kemudian diresuspensi dalam asam asetat yang mengandung $\mathrm{NaCl}$ dan deoxycholic acid sampai protein mencapai konsentrasi $0,5 \mathrm{mg} / \mathrm{mL}$ (pelarut alkohol absolut). Tahapan akhir adalah proses mencampur dengan pelet komersil di dalam bak besar hingga konsentrasi akhir protein dalam pakan mencapai $1 \mathrm{ng} / 6 \mathrm{mg}$ yang selanjutnya dikering-anginkan pada kondisi sekitar yang panas selama maksimal 5 jam. Setelah dikering- 
anginkan pelet pakan protein rekombinan $\mathrm{GH}$ dapat diaplikasikan untuk budidaya ikan.

\section{KESIMPULAN}

Telah dilakukan konstruksi rGH yang menghasilkan bakteri E. coli BL21 (DE3) yang mampu memproduksi protein $\mathrm{rGH}$. Produksi rGH dilakukan pada bioreaktor. Proses isolasi produk rGH-nya dalam bentuk pelet inclusion bodies yang selanjutnya dicampur dengan pelet pakan komersil hingga konsentrasi akhir protein dalam pakan mencapai $1 \mathrm{ng} / 6 \mathrm{mg}$ pakan, di mana setelah dikering-anginkan, pelet pakan protein rekombinan $\mathrm{GH}$ dapat diaplikasikan untuk budidaya ikan kerapu tikus dan ikan budidaya lainnya.

\section{UCAPAN TERIMA KASIH}

Terima kasih kepada Ken Ratih Probosari yang telah melakukan konstruksi pBlueKNKT. Penelitian ini dibiayai dari Riset Unggulan Strategis Nasional Tahun 2008-2009 dari Kementerian Ristek dan DIPA BPPT Tahun 2009.

\section{DAFTAR ACUAN}

Anonymous. 2004. pETBlue System Manual. User Protocol TB249 Rev. A 0204. USA.

Acosta, J., Morales, R., Morales, A., Alonso, M., \& Estrada, M.P. 2007. Pichia pastoris Expressing Recombinant Tilapia Growth Hormone Accelerates. The Growth of Tilapia. Springer Science Business Media.

Hayami, T., Sato, N., Ichiryu, T., Inoue, Y., Murata, K., Kimura, S., Nonaka, M., \& Kimura, A. 1989. Production of Recombinant Tuna Growth Hormone by a Yeast (Saccharomyces cerevisiae). Institute for Research and Development, Taiyo Fishery Co., Ltd. Agric. Biol. Chem., 53(1 1): 2,917-2,922.
Jeh, H.J., Kim, C.H., Lee, H.K., \& Han, K. 1997. Recombinant flounder growth hormone from Escherichia coli: overexpression, efficient recovery, and growth-promoting effect on juvenile flounder by oral administration. Biotech Research Institute, L.G. Chem Research Park, P.O. Box 61, Yu Song, Science.

Kapuscinski, A.R. \& Hallerman, E.M. 1990. Transgenic Fish and Public Policy: anticipating environmental impacts of transgenic fish. Fisheries, 15: 2-11.

Probosari, K.R. 2009. Kloning Gen Hormon Pertumbuhan Ikan Kerapu Tikus (Cromileptes altivelis) pada Vektor Ekspresi Protein Rekombinan. Tesis. Program Magister Bioteknologi Perikanan dan Kelautan, Fakultas Perikanan dan IImu Kelautan, Universitas Brawijaya.

Sambrook, J. \& Russell. 2001. Molecular Cloning; a Laboratory Manual. Second Edition. Coldspring Harper Laboratory Press. New York.

Syaifuddin, M., Alimuddin, Widyastuti, U., Sudrajat, A.O., Sumantadinata, K., \& Aliah, R.S. 2007. cDNA encoding growth hormone from humpback grouper (Cromileptes altivelis). BIOTROPIA, 14(2): 1-6.

Tsai, H.J., Lin, K.L., Kuo, J.C., \& Chen, S.W. 1995. Highly efficient expression of fish growth hormone by Escherichia coli cells. Applied and Environmental Microbiology, 61 : 4,1 16 $4,119$.

Tsai, H.J., Hsih, M.H., \& Kuo, J.C. 1997. Escherichia coli-produced fish growth hormone as a feed additive to enhance the growth of juvenile black seabream (Acanthopagrus schlegeli). J. Appl. Ichthyol., 13: 79-82.

Watahiki, M., Ohara, E., \& Tsuda, M. 1992. Syntheses of recombinant yellowtail and flounder growth hormones in Escherichia coli. Biosci. Biotech. Biochem., 56: 1,012-1,016. 